\title{
Assessing and Evaluating Anthropogenic Activities Causing Rapid Evolution in the Coastal Morphological Landscape Changes (CMLC) of Kuwait Using RIAM
}

\author{
S. Baby (Corresponding author) \\ Department of Remote Sensing \& Geoinformatics \\ Birla Institute of Technology, Ranchi 835215, India \\ $\&$ \\ GEO Environmental Consultation, Hawally \\ PO Box 677, Al-Surra 4507, State of Kuwait \\ E-mail: sajimathewvk@hotmail.com
}

Received: September 26, 2011

Accepted: October 16, $2011 \quad$ Published: December 1, 2011

doi:10.5539/enrr.v1n1p152

URL: http://dx.doi.org/10.5539/enrr.v1n1p152

\begin{abstract}
Rapid Impact Assessment Matrix (RIAM), developed by DHI, is a preliminary assessment and scoping tool that was applied for performing the task of Rapid Assessment Procedure (RAP) in order to study the Coastal Morphological Landscape Changes (CMLC) for the coast of Kuwait. The obtained RIAM results were evaluated by conducting $\sum$ of Environmental Score (ES); Range Values Frequency Balance; Segregating Range Value and Environmental Score; and Histogram Evaluation. The RIAM study gives clear indication that the anthropogenic activities in Kuwait has been and is interfering with environmental components; thereby bringing changes or modifying or altering the natural CML. The activities of oil refineries, oil terminals, petrochemical industries, power stations and desalination plant have had more impact in changing the coastal morphology from the time oil was first discovered till now. They have changed the geomorphologic landforms and have interacted with salt marshes, swamps, tidal and intertidal flats of Kuwait. Apart from that the activities of dredging, dumping, reclamation, shore and beach nourishment, beach repair and construction have induced unpredicted erosion and accretion along the coast. The limited natural CML resources of the coastal area in Kuwait which lies along the 325 kilometers of shoreline of mainland inaddition, the coastal area of nine islands would become extinct within the next few decades if such acceleration of coastal exploitation goes on without any stringent preservation and conservation strategies. The total shoreline including all the nine islands is about 500 kilometers in length. The most vulnerable coast of Kuwait is around the Kuwait Bay, Khor Subiya Creek, and 1slands of Bubiyan, and Warba.
\end{abstract}

Keywords: Range value, Environmental score, RIAM scoping, RV frequency balance, Coastal morphology, Landscape

\section{Introduction}

Kuwait's geography has great diversity of coastal landscape morphology that reflects the differences in biophysical conditions and cultural heritage. These array of desert landscape features or landforms are contrast in both spatial and temporal terms. They include a number of landscape features that develop as relatively important ecological habitats as well as cultural features that are evolved rapidly due to anthropogenic intervention and conflict. The major threat to coastal landscapes of Kuwait is related to uncontrolled development, urbanization; land based pollution, population migration, and unplanned or over exploited natural resources. Human interference and development have posed considerable damage to the dynamic coastline of Kuwait since the last fifty years. The discovery of petroleum, its related development and economic growth, has exploited the coast, thereby altering the morphological landscape through built up structures, population migration, coastline change, habitat change and land use. As a result Kuwait's coastal landscape is modified at a tremendous pace. Linked to a rich and interesting past, Kuwait's landscape has been subjected to extraordinary changes - primarily through topographic modification. It is known that the physiognomy of a coastal landscape is created by physical, 
geological, meteorological and biological factors, greatly modified over time by human activity (Vogiatzakis, et al. 2005).

In the plurality inherent of the concept of landscape lie both the strength and the weakness as a setting for conservation. It is apparent that the term 'landscape' means different things to different people, notwithstanding common elements. Hence, according to UNEP (2007) the term has a number of meaning and association. Despite the multitude of definitions put forth, there are three aspects that make landscapes much more naturally passive features in people's everyday lives. Firstly, the impact of landscape is felt through the senses. Secondly, landscape has a two-way relationship with people, and with the power to shape and reinforce values, to inspire, to calm and to reinforce a sense of identity. Thirdly, landscape embodies past record of human land-use and ancestry. Landscape hence constitutes a meeting ground of nature and people, past and present, tangible and intangible values. As a result, landscape is increasingly being recognized as particularly relevant to the quest for more sustainable ways of living. It has several characteristics which echo concepts of sustainable development, such as its universality, its dynamicity and the fact that it is holistic yet hierarchical. By this implication, landscape is not merely an environmental resource in its own right, but also a means through which to pursue sustainable development (Phillips 2005). Since landscapes are multifunctional, encompassing numerous facets, and because they can be identified easily, as a highly aesthetic backdrop to people's everyday life, they provide an ideal arena for conservation efforts. Moreover, landscape also has unquantifiable values, ranging from pragmatic economic values to ecological, recreational, health-related and spiritual values (UNEP, 2007).

Christopher Pastakia, from 'DHI Water, Environment \& Health' is the creator of the Rapid Impact Assessment Matrix (RIAM) system and the Pastakia Principle. The concept of RIAM was developed by him in the late 1980 's, and coalesced into a system to demonstrate the degree of change in engineering project options and interventions. This was applied first in water resource and river management projects in Bangladesh in 1991-92. RIAM allows full transparency of the decisions made in an assessment study (Pastakia, 1998). The RIAM system is based on simple concepts and has been tested in a number of different conditions. It is a very powerful tool in connection with EIA's and was tested on various project studies (Jensen, 1998) where a multi-disciplinary team approach is used (Morris \& Biggs, 1995). It allows data from different environmental, social and economic sectors to be analyzed against common important criteria within a common matrix, thus providing a rapid, clear assessment of the major impacts. It depicts the scoring within a matrix that has been designed to allow subjective judgments to be quantitatively recorded for assessment of coastal morphological landscape changes of Kuwait in relation to various developmental projects along the coast. This paper uses the concept of RIAM to assess the human cause and development to rapidly changing coastal morphological landscape of Kuwait.

\section{Study Area and Main Focus}

The mainland shoreline of the coast of Kuwait is about 325 kilometers long. The total shoreline including all the nine islands is about 500 kilometers in length (Neelamani and Khaled, 2005). The study of the morphological landscape change assessment was executed for the coast of Kuwait including the nine Islands (Fig. 1), extending between latitudes $28^{\circ} 30^{\prime} \mathrm{N}$ and $30^{\circ} 05^{\prime} \mathrm{N}$ and longitudes $46^{\circ} 3^{\prime} \mathrm{E}$ and $48^{\circ} 35^{\prime} \mathrm{E}$ bordering the Arabian Gulf between Iraq and Saudi Arabia. The islands (Bubiyan, Warba, Failaka, Kubar and Garouh) are mostly influenced by human interferences and the coastal morphological landscape have changed rapidly since then and more changes are expected to occur in the future.

This study utilizes RIAM to assess the Coastal Morphological Landscape Changes (CMLC) due to anthropogenic developmental projects. The natural causes and processes have been avoided in this study, although it is known that the causes like waves, tides, currents and storms; climatic and water level changes and coastal vegetation have long term influence in shaping the coastal landscape. The study mainly pays attention to human induced influence on the CMLC.

\section{Objectives}

The objectives of the study are:

- To conduct a study different from conventional application of RIAM, with an objective to adapt and apply RIAM to evaluate CMLC of Kuwait caused by developmental projects.

- To assess the anthropogenic factor (i.e. human induced) that influences the CMLC (i.e. physical shape and dimension) and rapid evolution.

- To determine the importance of human induced activities that affects and alters the coastal shape and dimension. 
- To determine the weight, by setting up a matrix with defined components to compare with and without developmental project situation on the coast of Kuwait.

- To use RIAM as Rapid Assessment Procedure (RAP) to determine the Human causes and severity in coastal morphological evolution of coast.

\section{RIAM Theory}

RIAM requires the assessor defining components (process of scoping) that are important indicators of change (either positive or negative). These environmental components fall into one of the four categories which are defined below:

1) Physical and Chemical (PC)

2) Biological and Ecological (BE)

3) Social and Cultural (SC)

4) Economic and Operational (EO)

The use of these four categories can be in itself a competent tool for EIA, though each category can be further sub-divided to identify specific environmental components that would better demonstrate the possible impacts. The degree of sensitivity and detail of the system can thus be controlled by the selection and definition process for these environmental components.

The Rapid Impact Assessment Matrix (RIAM) method is based on a standard definition of the important assessment criteria as well as the means by which semi-quantitative values for each of these criteria can be collated to provide an accurate and independent score for each condition (Pastakia, 1998). The impacts of project activities are evaluated against the environmental components and for each component a score (using the defined criteria) are determined, which provides a measure of the impact expected from the component. The criteria should be defined for both groups, and should be based on fundamental conditions that may be affected by change rather than being related to individual projects.

It is theoretically possible to define a number of criteria, but two principles should always be satisfied (Pastakia, 1998):

1) The universality of the criterion, to allow it to be used in different EIAs.

Note: 5- criteria have been developed for use in the RIAM. Nevertheless, these five criteria represent the most important fundamental assessment conditions for all Environmental Impact Assessments (EIAs), and satisfy the principles set out. These criteria, together with their appropriate judgment scores are defined as Group A and Group B.

2) The value of the criterion determines whether it should be treated as a Group (A) or Group (B) condition (Jensen, 1998; Pastakia \& Jensen, 1998):

A. Criteria that are of importance to the condition, and which can individually change the score obtained.

B. Criteria that are of value to the situation, but individually should not be capable of changing the score obtained.

The value ascribed to each of these groups of criteria is determined by the use of a series of simple formulae (Pastakia, 1998). These formulae allow the scores for the individual components to be determined on a defined basis.

The scoring system requires simple multiplication of the scores given to each of the criteria in group (A). The use of multiplier for group (A) is important, for it immediately ensures the weight of each score expressed, whereas simple summation of scores could only provide identical results for different conditions.

Scores for the value criteria group (B) are added together to provide a single sum. This ensures that the individual value scores cannot influence the overall score, but the collective importance of all values in group (B) is fully taken into account. The sum of the group (B) scores is then multiplied by the result of the group (A) scores to provide a final environmental score (ES) for the condition.

The process can be expressed (Pastakia \& Madsen, 1995):

$$
\text { (al) } \mathrm{x}(\mathrm{a} 2)=\mathrm{aT}
$$

$$
(\mathrm{b} 1)+(\mathrm{b} 2)+(\mathrm{b} 3)=\mathrm{bT}
$$




$$
(\mathrm{aT}) \mathrm{x}(\mathrm{bT})=\mathrm{ES}
$$

Where:

(a1) and (a2) are the individual criteria scores for group (A)

(b1) to (b3) are the individual criteria scores for group (B)

$\mathrm{aT}$ is the result of multiplication of all (A) scores

$\mathrm{bT}$ is the result of summation of all (B) scores

ES is the assessment score for the condition.

Positive and negative impacts can be demonstrated by using scales that pass from negative to positive values through zero for the group (A) criteria. Zero thus becomes the 'no-change' or 'no-importance' value. The use of zero in this way in group (A) criteria allows a single criterion to isolate conditions which show no change or are unimportant to the analysis.

Zero is a value avoided in the group (B) criteria. If all group (B) criteria score zero, the final result of the ES will also be zero. This condition may occur even where the group (A) criteria shows a condition of importance that should be recognized. To avoid this, scales for group (B) criteria use ' 1 ' as the 'no-change/no-importance' score.

To use the evaluation system described, a matrix is produced for each project option (Table 1). The matrix comprises of cells showing the criteria used, set against each defined component. Within each cell the individual criteria scores are set down. From the formulae given above, each ES number is computed and recorded.

No claim is made for the sensitivity of any ES value, and to provide a more certain system of assessment, the individual ES scores are banded together into ranges (Range values: RV) where they can be compared (Table 2).

Ranges are defined by conditions that act as markers for the change in bands. These conditions would normally reflect the changes in group (A) scores, combined with the upper or lower scores possible with the group (B) criteria.

Conditions have been defined to produce range values covering \pm 5 , and the limits of the bands in this range can be defined as follows:

- Conditions that have neither importance nor magnitude will score a zero, and can be banded together. Any condition in this band is either of no importance, or represents the status quo, or a no change situation.

- A condition that is local in importance $(\mathrm{A} 1=1)$, and a slight change from the status quo $(\mathrm{A} 2=1)$, yet is permanent $(B 1=3)$, irreversible $(B 2=3)$ and cumulative $(B 3=3)$, represents the upper limit of the 'slight change' condition.

- A condition of 'change' will occur up to a condition of local importance (A1=1) with significant magnitude $(\mathrm{A} 2=2)$, that is permanent $(\mathrm{B} 1=3)$, irreversible $(\mathrm{B} 2=3)$ and cumulative $(\mathrm{B} 3=3)$.

- A condition of moderate change will lie between the limits of 'change' and 'significant change'.

- The lower limits of 'significant change' can be taken as the point when a condition is outside local boundaries $(\mathrm{A} 1=2)$ but is of major importance $(\mathrm{A} 2=3)$, yet is temporary $(\mathrm{B} 1=2)$, reversible $(\mathrm{B} 2=2)$ and non-cumulative $(\mathrm{B} 3=2)$.

- A 'major change' will occur at a point when the condition extends to a regional / national boundary $(\mathrm{A} 1=3)$ and is of major importance $(\mathrm{A} 2=3)$. Such a change would also be permanent $(\mathrm{B} 1=3)$, irreversible $(\mathrm{B} 2=3)$, though it could be non-cumulative $(\mathrm{B} 3=2)$.

It should be noted that there are exceptions when B1, B2 and B3 are not always 2 and 3 . In such cases the above examples seems confusing e.g. the upper limit will be $\mathrm{A} 1=4, \mathrm{~A} 2=3$ and $\mathrm{b} 1-2-3=3$. The same range bands are used for negative impacts with negative numbers (-1 to -5). Once the ES score is set into a range band, these can be shown individually or grouped according to component type and presented in whatever graphical or numeric form that the presentation requires. After the computational calculations, RIAM classifies the degree of the damage or benefit (De Araujo, et al.; 2005), according to Table 2.

The sensitivity of the ranges is still based on subjective definition of range bands. This does not permit more sensitive bands to be easily formed, and the present system may not be sensitive enough for use in marginal or fragile environments (Table 2). However, experiment has shown that a \pm 5 range band is as sensitive as can be developed for a 5-criteria matrix, and such a range band is shown in Table 2 (with both numeric and alphabetic $\mathrm{RV}$ values). 


\section{Approach and Methodology}

RIAM (Pastakia, 1998) is a method used to evaluate all sorts of environmental impacts, and is applied as preliminary assessment tool to study the CMLC. RIAM method is based on a standard definition of the important assessment criteria as well as the means by which semi-quantitative values for each of these criteria can be collated to provide an accurate and independent score for each condition. In this study the impacts of developmental projects are evaluated against the coastal landscape morphology and a score (using the defined criteria) is determined (De Araujo, et. al, 2005), which provides the measure of the impact on coastal landscape expected from the developmental projects (activities). To study CMLC, application of RIAM was carried out in steps as shown in Fig.2.

Step I: Classification of Coastal Developments

Coastal developmental projects in Kuwait were classified (for RIAM application) as OPs as given in Table 3:

Step II: Important Consideration

- Bubiyan, Warba, Failaka and Garouh are the most affected islands due to human induced developments.

- The shoreline of Kuwait is under pressure of booming unmanaged over-development.

- Increase in coastal settlements and residential areas and other activities.

- As Kuwait's economy transforms with oil based industries, coastal ecosystems have been exposed to significant environmental challenges, causing significant changes in the geomorphology of the coast, directly or induced.

- The changed geomorphology has intensified pressure on coastal natural resources and vice-versa.

- The fragile coastal zone is suffering from human activities, which plays an important role in shaping the morphology of coast.

- The coast of Kuwait is categorized into two main parts. One extending along the Arabian Gulf and the other around the Kuwait Bay and Khor Subiya Creek. Most of the former area is characterised by sandy beaches because it is exposed to sea currents and waves, while the latter, $70 \mathrm{~km}$ in length, is characterised by mudflats, especially in the shallow northern area of the Bay of Kuwait which faces Kuwait city, where the maximum wave height is $26 \mathrm{~cm}$. The tidal movement is semi-diurnal, which occurs twice a day.

\section{Step III: RIAM Scoping}

RIAM scoping exercise was performed to determine the important coastal environmental components as listed in table 4 for each of the four categories and allows decisions on these components to be made and recorded, by assessing the beneficial or negative impacts against defined criteria and scales. Because of the simplicity of the RIAM System, its results are capable of rapid presentation in the form of graphical formats or alpha-numeric scaling. The different environmental components were identified based on field investigation and description used from the published paper by Abou Seida \& Al-Sarawi (1990), and was grouped into four types (Table 4) based on RIAM input (Pastakia, 1998):

It would have been more appropriate to break down some of the components (in Table 4) as it would be easier to work with more simple components rather than a multi-type criteria (Table 4) if the study was dealing with all the impacts on each components separately. In such situations for example: BE3: Salt march, swamp, tidal flats and inter tidal flats will often be located at different sites and therefore should be handled as separate components. The same goes for BE4: Corals, oysters and mud skippers inhabit different habitats and will accordingly react differently to impacts and also to different mitigating measures: Given each a separate component-line. In contrary in this study it was grouped together based on the common type of components existing in Kuwait rather than the location which is impacted and supports the main objective of the study focusing on evolution in the Coastal Morphological Landscape Changes (CMLC).

\section{Step IV: Expert Opinion}

Expert opinion also known as content analysis on the impact development was sought from 5 experts with expertise in coastal zone management, coastal engineering, coastal hydrodynamics, coastal environment and coastal ecology. They are well familiar with the coast of Kuwait.

The RIAM matrix chart was prepared to get their input values (pre-prescribed values) for criteria A1, A2, B1, B2 and $\mathrm{B} 3$ which corresponds to 2 options i.e. conditions with and without activities along the coast. Ranking 
method was adopted and expert had to choose numbers from pre-assigned numerical values. The experts were supplied with the following information:

- The objective of the task.

- Two options: one with project / activities (OPa) and another without project / activities ( $\mathrm{OPb})$.

- Coastal projects were classified into a list of 5 developmental projects.

- 5 developmental projects activities were grouped under 4 categories (PC, BE, SC, EO).

- Each category was further sub divided into coastal environmental components and their list.

The response received from the 5 experts was evaluated for the input values for criteria to find the range of disparity. A statistical analysis was performed for the numbers obtained from the experts. The value which got the 'highest polling' among the 5 values was considered to derive a single value for the criteria A1, A2, B1, B2 and B3. In a few cases it was hard to decide the choice of the values from the 5 expert (for example a set of value $2,2,3,3,1$ or $2,-2,3,1)$. In such cases the questionnaire with that particular section was resent to the experts to reconsider their opinion or otherwise provide their own opinion for selecting single values.

Step V: RIAM Software and Scaling

A Matrix was generated using RIAM software for criteria A and B (considered with and without development project). This value for the criteria A1, A2, B1, B2 and B3 obtained from step VI was entered into the matrix chart in the computer. To use the evaluation system described, a matrix was produced for each project option. By setting up a matrix with defined components, it was possible to compare with and without project situation. aT and bT values were derived from computation. ES score was derived from RIAM program. ES score and its scaling were assessed for CMLC. Graphs were generated for study.

\section{Results and Discussion}

The study is based on 15 categories of development activities, those which are prominent in Kuwait coastal area, which have an impact on the 27 environmental components of $\mathrm{PC}, \mathrm{BE}, \mathrm{SC}$ and $\mathrm{EO}$ and which would change or induce coastal morphological landscape (CML) directly or indirectly. On the other hand, the activities far away from Kuwait and not within it's geographical and political boundaries can also induce coastal changes in Kuwait.

The numerical values and alphabetic grading was observed and studied for RV and ES (Table 5). Considering No-Go-Project option means without any anthropogenic developmental activities or project along the coast that would not alter CML either directed or indirectly or induced (OP1b-15b). The 15 different OPs are mentioned in Table 2. ' $a$ ' denotes with project and ' $b$ ' denotes without project. The coastal land use for oil exploration in Kuwait is not seen. In such case the interaction with coastal morphology is considered negligible. Almost all the oil fields are away from the coast and is situated inland or off-shore. In such case the values for OP3a mimics the No-Go-Project.

The summation for the RV values is given for all the activities OP1a-15a for PC, BE, SC and EO (Fig. 3)

\subsection{Histogram Evaluation}

If we observe the histogram for the list of activities in Figure 4, it is interesting to note that the negative values are of 'PC' and 'BE' and positive values are of 'SC' and' $\mathrm{EO}$ '.

The values of 'PC' and 'BE' determine the impact towards the alteration of CML. The values of 'SC' and 'EO' determines the socio-economic development. If we consider the RV values for the 'PC' it can be seen that it is highest for activities in OP1a followed by OP4a, OP7a and OP6a. For RV values for 'BE' it can be seen that it is highest for activities in OP5a followed by OP1a, and OP4a.

$6.2 \sum$ of ES

The summation ' $\sum$ ' for the ES was carried out in two directions (Table 5): (i) X-axis for each environmental components and (ii) Y-axis for each coastal developmental activity. These give weight to each factor and enable us to understand the important causes that impact the CML and bring alteration. In our study we are mainly looking at the negative values which are the direct causes. The higher negative values means higher impact on CML alteration. The series starts with higher positive value and moves towards the more negative values. The higher negative value means higher impact in altering CML.

$X$-axis $\sum$ of ES for environmental components in decreasing order from + ve to -ve:

$+324(\mathrm{EO} 3)>+306(\mathrm{SC} 8)>+246(\mathrm{EO} 2)>+210(\mathrm{EO} 1)>+203(\mathrm{EO})>+184(\mathrm{EO} 4)>+62(\mathrm{EO})>+40(\mathrm{SC} 5)>$

$-69(\mathrm{SC} 4)>-104(\mathrm{PC} 3)>-210(\mathrm{PC} 5)>-229(\mathrm{BE} 4)>-230(\mathrm{BE} 5)>-234(\mathrm{BE} 3)>-245(\mathrm{PC} 2)>-253(\mathrm{SC} 2)>$ 
$-258(\mathrm{BE} 1 \& \mathrm{SC} 6)>-260(\mathrm{PC} 7)>-276(\mathrm{PC} 8)>-285(\mathrm{PC} 4)>-298(\mathrm{PC} 6)>-306(\mathrm{SC} 1)>-310(\mathrm{BE} 2 \& \mathrm{SC} 3)>$ $-342(\mathrm{SC} 7)>-345(\mathrm{PC} 1)$

Observing the above series of $\sum$ for ES it can be understood, that the most sensitive environmental components which determine the natural CML change is from: (i) rapid evolution of coastline and shore; (ii) obstruction in natural site view; (iii) removal of habitat favoring mangrove and seagrass; (iv) change in coastal land cover; (v) migration of human habitat and urban sprawl towards coast; (vi) coastal land degradation; (vii) pollution; (viii) direct encroachment on natural geomorphology; (ix) coastal conflict; (xi) removal of coastal vegetation; (xii) disturbance to enjoy natural marine environment; (xiii) disturbance to fish habitat; (xiv) causing unbalanced erosion and accretion; (xv) extinction of salt marshes, swamps, tidal and intertidal flats; (xvi) coastal terrestrial ecosystem such as sand dunes, etc.; (xvii) disturbance in ecology of corals, (xviii) oysters and mudskippers; and (xiv) disappearance of natural beaches.

$Y$-axis $\sum$ of ES for each activity in decreasing order from +ve to -ve:

$+15(\mathrm{OP} 13 \mathrm{a})>0(\mathrm{OP} 3 \mathrm{a})>-30(\mathrm{OP} 12 \mathrm{a})>-44(\mathrm{OP} 7 \mathrm{a})>-85(\mathrm{OP} 11 \mathrm{a})>-94(\mathrm{OP} 15 \mathrm{a})>-99(\mathrm{OP} 14 \mathrm{a})>-107(\mathrm{OP} 10 \mathrm{a})>$ $-110(\mathrm{OP} 8 \mathrm{a})>-174(\mathrm{OP} 9 \mathrm{a})>-372(\mathrm{OP} 2 \mathrm{a})>-438(\mathrm{OP} 6 \mathrm{a})>-509(\mathrm{OP} 1 \mathrm{a})>-524(\mathrm{OP} 5 \mathrm{a})>-676(\mathrm{OP} 4 \mathrm{a})$

Similarly, observing the above series of $\sum$ for ES, it can be understood that the most harmful activities that change CML are: (i) pipeline, outfall of sewage, intake-outfall of desalination plants, intake-outfall of cooling system, outfall of sewage; (ii) dredging, dumping, reclamation, shore and beach nourishment, beach repair, coastal construction; (iii) oil refineries and related activities, petrochemical industries, power stations, desalination plants; (iv) beach sand mining (v) sewage treatment plants; (v) beach houses; (vi) hotel, resorts, and restaurants; (vii) artificial beaches, islands, and reef (viii) groin, sea walls, riprap, revetment, breakwaters, (ix) sea and coastal defensive projects (x) waterfronts, aqua parks and artificial lagoons; (xi) new emerging townships, cities; (xii) shipyards, ports, harbors, marinas, etc.

\subsection{Segregating $R V$ and $E S$}

The impact on CMLC is studied by separating and segregating the individual values for RV and ES in the categories of $\pm \mathrm{C}, \pm \mathrm{D}$ and $\pm \mathrm{E}$ (Table 6), which brings major impact in the change of CML. It is observed that within $\mathrm{C}, \mathrm{D}, \mathrm{E}$ categories, the ES values PC, BE, SC are all negative except for the value for occupation and employment ( $\mathrm{SC} 8$ ) with positive $\mathrm{RV}=+\mathrm{E}$ and $\mathrm{ES}=+81$ interaction with OP1a. Similarly, the values of $\mathrm{EO}$ are all positive except the negative value for $\mathrm{EO} 3$ (real estate) with negative $\mathrm{RV}=-\mathrm{D}$ and $\mathrm{ES}=-36$ interaction with OP4 and EO6 (existing utilities) with negative $\mathrm{RV}=-\mathrm{C}$ and $\mathrm{ES}=-24$ interaction with OP4a.

The ES for C, D and E categorizes the impact from moderate to significant to extreme level for both negative and positive. The activities with lower ES, in the category of RV $=-\mathrm{C}$, is no less considered important towards changing CML.

Evaluating the RIAM numbers shows that the major concern is from the activities of RV values $-\mathrm{E}$ and $-\mathrm{D}$ having extremely and significantly negative impact in changing and altering the CML Kuwait. One of the main reasons is the unsustained development faced by the coast in the last few decades. It is interesting to note that the importance and contribution of sociological and cultural (SC) for exploiting the coast; it has influenced CML structure, interacting with components in the $\mathrm{PC}$ and $\mathrm{BE}$ categories.

The ES value of -72 (PC2) from OP5a is a clear indication that, dredging, dumping, reclamation, shore and beach nourishment, beach repair, and construction pose extremely serious threat to the natural coastal morphology of Kuwait. The ES value of -72 (PC7) from OP5a indicates conflict with human activities causing immense damage to CML.

The ES value of -72(PC7) from OP1a indicates, the projects of oil refinery complexes, oil terminals, petrochemical industries, power stations, and desalination plants have seriously damaged the CML and would pose future threat with new ones coming to meet the demand of Kuwait.

The positive value of $+\mathrm{E}(81)$ attained by occupation and employment (SC8) and $+\mathrm{D}$ attained by trade (EO1), commercial (EO2), Hospitality and tourism (EO4) and navigation (EO5) is interpreted to cause extreme and significant positive impact in terms of the economic prosperity. Un-sustained economic development has damaged the non-renewable coastal landscape morphology of Kuwait.

The activities in OP1 i.e. oil refineries, oil terminals, petrochemical industries, power stations and desalination plant have interacted more than any other activities with environmental components. Activities in OP1a have more impact in changing the coastal morphology from the time of oil first discovered till now. These activities 
have changed geomorphologic landforms and have interacted with salt marsh, swamp, tidal flats, and intertidal flats of Kuwait. Activities in OP1a and OP5a have induced unpredicted erosion and accretion along the coast.

The main activities which is responsible in changing the CML of Kuwait is due to the impacts from activities in OP1a, OP2a, OP4a, OP5a, OP6a, OP8a, OP9a, OP11a, OP14a and OP15a. The environmental components which are mostly affected by the these anthropogenic activities are identified as: coastline and shore; erosion and accretion; pollution; natural beaches; coastal land degradation; coastal conflicts of human activities; geomorphology landforms; vegetation; salt marsh, swamp, tidal flats, and intertidal flats; terrestrial ecosystem; human habitat and urban sprawl; coastal land cover; and site view.

\subsection{Contradiction and Justification}

According to Christopher Pastakia, the scores attributed to the individual A \& B criteria and the use of the RIAM formulae produce a result termed the Environmental Score (ES). The ES scores do not follow an algorithmic sequence, nor can they be seen as a linear scale of superiority. Any close examination of the RIAM scoring will show that many ES scores can be individually derived from a number of A \& B scoring configurations. Therefore the ES scores cannot, in themselves, be used as a guide to the condition of any component, nor do they have any mathematical value. Thus an attempt of any mathematical aggregation or $\sum$ of ES score numbers is considered not appropriate.

The ES scores do provide the entry point into the defined range bands for RIAM. The range bands have been tested, and Pastakia and Madsen found the final range of 11 bands (+/- 5 plus zero) was the most sensitive and justifiable during their research on RIAM.

Thus the only justifiable and supported figures to show environmental separation in the results of RIAM are the Range Values. Here again it was though not correct to aggregation of components mathematically, and so the Range Values were also defined as alphabetic characters to avoid this.

The summation ' $\sum$ ' for the ES was performed by the author and carried out as an approach towards preliminary assessment and evaluation. The theory says that it is not an appropriate way of interpretation according to the concept of the function and use of ES in RIAM. However, the studies conducted by the author in contradiction have given desired outcomes for this study. The summation was performed to come to get points with simple arithmetic addition to categorize or scale the environmental components and project activities into increasing and decreasing order. The aim was to: (i) identify the most highly concerned anthropogenic activities in the State of Kuwait that affects the CML and (ii) the most sensitive environmental components which is disturbed in the process of change in CML from the anthropogenic activities. This deviated study from conventional one is considered by author as the degree of freedom to use RIAM.

\subsection{RV Frequency Balance}

Among the total frequency of $405 \mathrm{RV}, 94$ is $+\mathrm{RV}$ (23.21\%); 261 is $-\mathrm{RV}$ (64.44\%); and 50 is Neutral RV $(12.35 \%)$. It is seen that the negative frequency is outnumbering the positive frequency. If we further split them according to the $\mathrm{A}, \mathrm{B}, \mathrm{C}, \mathrm{D}$, and $\mathrm{E}$ range classes it can be stated $+\mathrm{A}=60 ;-\mathrm{A}=27 ;+\mathrm{B}=38 ;-\mathrm{B}=106 ;+\mathrm{C}=17$; $-\mathrm{C}=50 ;+\mathrm{D}=11 ;-\mathrm{D}=42 ;+\mathrm{E}=1 ;-\mathrm{E}=3$.

A balance graph (Fig. 5) is used to see the weight of the frequency of + ve and -ve for RVs. It can be noted that the balance is leaning towards the -ve side. This gives clear indication that lots of anthropogenic activities in Kuwait has interfered and is interfering with environmental components thereby bringing changes or modifying or altering the natural CML.

It is to be noted that the activities with RV values with negative E should be considered extremely important; negative D significantly important; and negative $\mathrm{C}$ moderately important while taking the decision in sustained coastal management process and effective approach for development. The RV values for negative B and A should not be undermined. The activities interfering with the environmental components and possessing negative values for $\mathrm{PC} 1, \mathrm{PC} 2, \mathrm{PC} 4, \mathrm{PC} 5, \mathrm{PC} 6, \mathrm{PC} 7, \mathrm{PC} 8, \mathrm{BE} 1, \mathrm{BE} 2, \mathrm{BE} 3, \mathrm{BE} 4, \mathrm{BE} 5, \mathrm{SC} 1, \mathrm{SC}$, and $\mathrm{SC} 7$ are responsible for the changes in the CML.

Positive RVs in SC and EO give the sign for development. The positive values are scored due to positive views towards human comfort, economy, living condition, good transport, navigation, entertainment, and trade from the exploitation of coastal natural resources and neglecting the negative consequences of the environment. The civilization would survive only when the development is in place. If these developments are necessary to meet the demand of Kuwait, better options and alternatives should be considered which would avoid further encroachment of sensitive CML which remains untouched. The+ Coastal development in Kuwait is reaching a level where more encroachment would take place in the future towards the sensitive coastal areas on the north of 
Kuwait. It is wise and strictly important to declare a no-go-project at coastal areas of Kuwait within a certain buffer distance from the coastline.

\section{Conclusion}

It is a fact that diverse and complex natural processes persistently change coasts physically, chemically, and biologically, at scales that range from microscopic (grains of sand) to global (change in sea level), but human activity adds major dimension to coastal change by modifying and disturbing, both directly and indirectly, the coastal environment. The main human causes responsible for the tremendous change in Kuwait coastal morphology during the last 50 years are due to: Population dynamics and migration; Oil exploration and production; Economic growth; Technological change; Political and economical institution and Attitude and belief.

The top 5 environmental components among the list of 27, which are altered from the anthropogenic activities bringing the change in coastal morphological landscape, are: (i) Coastline and shore (ii) Site view (iii) Coastal land Cover (iv) Human habitat and urban sprawl (v) Coastal land degradation. These five components have impact on the natural coastal landscape morphology of Kuwait to a great extent in the shape, dimension and composition.

The top 5 group of anthropogenic activities among the 15, that is assessed as the cause for the coastal morphological landscape changes are: (i) Pipeline, outfalls, and intake (ii) Dredging, dumping, reclamation, shore and beach nourishment, beach repair, and construction (iii) Oil refineries complexes, oil terminals, petroleum industries, power stations, and desalination plants (iv) Beach sand mining (v) Sewage treatment plants and other establishments.

The activities of oil refineries, oil terminals, petrochemical industries, power stations and desalination plant have interacted more than any other activities with environmental components. These activities have more impacts in changing the coastal morphology from the time oil was first discovered till now. They have changed geomorphologic landforms and have interacted with salt marshes, swamps, tidal flats, and intertidal flats of Kuwait. Apart from that, the activities of dredging, dumping, reclamation, shore and beach nourishment, beach repair, and construction have induced unpredicted erosion and accretion along the coast.

In all, the main activities which are responsible in changing the CML of Kuwait are caused by the impacts from activities in OP1a, OP2a, OP4a, OP5a, OP6a, OP8a, OP9a, OP11a, OP14a and OP15a. The environmental components which are mostly affected by these anthropogenic activities are identified as: coastline and shore; erosion and accretion; pollution; natural beaches; coastal land degradation; coastal conflicts of human activities; geomorphology landforms; vegetation; salt marshes, swamps, tidal flats, and intertidal flats; terrestrial ecosystem; human habitat and urban sprawl; coastal land cover; and site view.

The RIAM study gives clear indication that anthropogenic activities in Kuwait have interfered and are interfering with environmental components thereby bringing changes or modifying or altering the natural CML. The most vulnerable coast of Kuwait is around the Kuwait Bay, Khor Subiya Creek, and lslands of Bubiyan, and Warba. The limited natural CML resources in the coastal area in Kuwait would be extinct within few decades if such an acceleration of coastal exploitation goes on without preservation and conservation strategies.

\section{Acknowledgements}

I extend my heartfelt gratitude to Dr. C.M.R. Pastakia, Environmental Advisor, Chelmsford, Essex, UK, the creator of RIAM, for his valuable time to review and enhance the paper and for expressing his willingness to extent his helping hand in the future.

My special thanks to Dr. Jesper Goodley Dannisøe, Senior Project Manager, Ecology \& Environment Department, DHI Water * Environment * Health, Denmark, for his valuable time to review the paper and for his valuable comments.

I am also thankful to Dr. Arne Jensen, DHI Water * Environment * Health, Denmark, for his review and comments which has helped me in the input of results and discussion.

I am thankful to Ms. Cynthia Fernandes, GEO Environmental Services, Kuwait for editing and formatting the paper to give its final form.

I am thankful to Dr. S. Neelamani, Senior Scientist and Dr. Karim Raka, Senior Scientist of Kuwait Institute for Scientific Research, Kuwait for patiently supporting me to prepare the questionnaire. 


\section{References}

Abou Seida, M., \& Al-Sarawi, M.A. (1990). Utilization and Management of Coastal Areas in Kuwait. Coastal Management. Taylor and Francis ,USA (Publisher), 18, 385-401.

De Araujo, P. S. F., Moura, E. F. S. C., \& Haie, N. (2005). Application of RIAM to the Environmental Impact Assessment of Hydroelectric Installations. The Fourth Inter-Celtic Colloguium on Hydrology and Management of Water Resources. Guimaraes, Portugal, July 11-14, 2005.

DHI, (2011). RIAM - an Environmental Impact Assessment tool. [Online] Available: http://www.dhigroup.com/SolutionSoftware/RIAM.aspx

Jensen, K. (1998). Environmental Impact Assessment Using the Rapid Impact Assessment Matrix (RIAM). Olsen \& Olsen (Publisher), Fredensborg, Denmark, pp. 69.

Morris, P., \& Biggs, J. (1995). Water. In: P. Morris \& R. Therivel (eds). Methods of Environmental Assessment, UCL Press, UK.

Neelamani, S. \& Al-Banna, K. (2005). Environmental Friendly Floating Breakwaters for Protecting the Islands and Coasts against Erosion. In: Proceedings of the Second Gulf Conference on Environment \& Sustainability, Kuwait, pp. 255-267.

Pastakia, C.M.R. (1998). The Rapid Impact Assessment Matrix (RIAM) - A New Tool for Environmental Impact Assessment. In: Kurt Jensen (ed.), Environmental Impact Assessment Using the Rapid Impact Assessment Matrix (RIAM), Olsen \& Olsen, Fredensborg, Denmark.

Pastakia, M.R.P., \& Jensen, A. (1998). The Rapid Impact Assessment Matrix (RIAM) for EIA. Environ Impact Asses. Rev., 18, 461-482.

Pastakia, C.M.R., \& Madsen, K. N. (1995). A Rapid Assessment Matrix for Use in Water Related Projects. Presented to the Stockholm Water Conference, August, 1995. Impact Assessment. UCL Press, UK.

Phillips, A. (2005). Landscape as a meeting ground: Category V Protected Landscapes/Seascapes and World Heritage Cultural Landscapes. In: J. Brown, N. Mitchell and M. Beresford, eds. The Protected Landscape Approach: Linking Nature, Culture and Community. Gland, Switzerland: IUCN, 19-35.

Rapid Assessment Matrix, (1998). [Online] Available: http://www.pastakia.com/riam

Vogiatzakis, I. N., Griffiths, G. H., Cassar, L. F., \& Morse, S. (2005). Mediterranean Coastal Landscapes. Management Practices, Typology and Sustainability. The Living Landscapes Project at The University of Reading. University of Reading, UK, pp. 50. 
Table 1. Criteria and scaling

\begin{tabular}{|c|c|c|c|c|}
\hline $\begin{array}{l}\text { Group } \\
\text { Criteria }\end{array}$ & $\begin{array}{l}\text { Sub Group } \\
\text { Criteria }\end{array}$ & Criteria Description & $\begin{array}{c}\text { Scal } \\
\mathrm{e}\end{array}$ & Scale Evaluation Description \\
\hline \multirow{12}{*}{$\begin{array}{l}\text { Group (A) } \\
\text { Criteria } \\
\text { that are of } \\
\text { importanc } \\
\text { e to the } \\
\text { condition, } \\
\text { that can } \\
\text { individuall } \\
\text { y change } \\
\text { the score } \\
\text { obtained. }\end{array}$} & \multirow{5}{*}{$\begin{array}{c}\text { A1 } \\
\text { Importance } \\
\text { of } \\
\text { Condition }\end{array}$} & \multirow{5}{*}{$\begin{array}{l}\text { A measure of the importance of the } \\
\text { condition, which is assessed against the } \\
\text { spatial boundaries of human interests it } \\
\text { will affect. The scales are defined: }\end{array}$} & 4 & $\begin{array}{l}\text { Important to international } \\
\text { interests }\end{array}$ \\
\hline & & & 3 & Important to national interests \\
\hline & & & 2 & $\begin{array}{l}\text { Important to areas immediately } \\
\text { outside the local condition }\end{array}$ \\
\hline & & & 1 & $\begin{array}{c}\text { Important only to the local } \\
\text { condition }\end{array}$ \\
\hline & & & 0 & Not importance \\
\hline & \multirow{7}{*}{$\begin{array}{c}\text { A2 } \\
\text { Magnitude } \\
\text { of } \\
\text { Change/ } \\
\text { Effect }\end{array}$} & \multirow{7}{*}{$\begin{array}{l}\text { Magnitude is defined as measure of the } \\
\text { scale of benefit/dis-benefit of an impact } \\
\text { or a condition: }\end{array}$} & +3 & Major positive benefit \\
\hline & & & +2 & $\begin{array}{c}\text { Significant improvement in status } \\
\text { quo }\end{array}$ \\
\hline & & & +1 & Improvement in status quo \\
\hline & & & 0 & No change/status quo \\
\hline & & & -1 & Negative change to status quo \\
\hline & & & -2 & $\begin{array}{l}\text { Significant negative dis-benefit } \\
\text { or change }\end{array}$ \\
\hline & & & -3 & Major dis-benefit or change \\
\hline \multirow{9}{*}{$\begin{array}{l}\text { Group (B) } \\
\text { Criteria } \\
\text { that are of } \\
\text { value to } \\
\text { the } \\
\text { situation, } \\
\text { but should } \\
\text { not } \\
\text { individuall } \\
\text { y be } \\
\text { capable of } \\
\text { changing } \\
\text { the score } \\
\text { obtained. }\end{array}$} & \multirow[t]{3}{*}{ B1 } & \multirow{3}{*}{$\begin{array}{l}\text { Permanence is defined as: Whether a } \\
\text { condition is temporary or permanent, } \\
\text { and should be seen only as measure of } \\
\text { the temporal status of the condition }\end{array}$} & 1 & No change/not applicable \\
\hline & & & 2 & Temporary \\
\hline & & & 3 & Permanent \\
\hline & \multirow[b]{3}{*}{$\begin{array}{c}\text { Reversib } \\
\text { ty }\end{array}$} & \multirow{3}{*}{$\begin{array}{c}\text { Defines whether the condition can be } \\
\text { changed and is a measure of the control } \\
\text { over the effect of the condition (Jensen, } \\
\text { 1998). }\end{array}$} & 1 & No change/not applicable \\
\hline & & & 2 & Reversible \\
\hline & & & 3 & Irreversible \\
\hline & \multirow{3}{*}{$\begin{array}{c}\text { B3 } \\
\text { Cumulativ } \\
\text { e }\end{array}$} & \multirow{3}{*}{$\begin{array}{l}\text { Measure of whether the effect will have } \\
\text { a single direct impact or whether there } \\
\text { will be a cumulative effect over time, or } \\
\text { a synergistic effect with other } \\
\text { conditions. The cumulative criterion is a } \\
\text { means of judging the sustainability of a } \\
\text { condition, and is not to be confused with } \\
\text { a permanent/irreversible situation. }\end{array}$} & 1 & No change/not applicable \\
\hline & & & 2 & Non-cumulative/single \\
\hline & & & 3 & cumulative/synergistic \\
\hline
\end{tabular}

Table 2. Environmental classifications according to RIAM

\begin{tabular}{|c|c|c|c|}
\hline $\begin{array}{c}\text { RIAM Environmental } \\
\text { Score (ES) }\end{array}$ & $\begin{array}{c}\text { Range Value (RV) } \\
\text { of Class (alphabetic) }\end{array}$ & $\begin{array}{c}\text { Range Value (RV) of } \\
\text { the class (numerical) }\end{array}$ & Description of the Range Band \\
\hline 72 to 108 & E & 5 & Extremely positive impact \\
\hline 36 to 71 & D & 4 & Significantly positive impact \\
\hline 19 to 35 & C & 3 & Moderately positive impact \\
\hline 10 to 18 & B & 2 & Less positive impact \\
\hline 1 to 9 & A & 1 & Reduced positive impact \\
\hline 0 & N & 0 & No alteration \\
\hline-1 to -9 & - A & -1 & Reduced negative impact \\
\hline-10 to -18 & -B & -2 & Less negative impact \\
\hline-19 to -35 & - C & -3 & Moderately negative impact \\
\hline-36 to -71 & -D & -4 & Significantly negative impact \\
\hline-72 to -108 & -E & -5 & Extremely negative impact \\
\hline
\end{tabular}


Table 3. Coastal developmental projects in 5 major categories in Kuwait

\begin{tabular}{|c|c|c|c|}
\hline & Major Categories & S. No. & Sub-categories / OPs (Options) \\
\hline \multirow{6}{*}{ A. } & \multirow{6}{*}{$\begin{array}{l}\text { Industrial Infrastructures and } \\
\text { Activities }\end{array}$} & 01 & $\begin{array}{l}\text { Oil refinery complexes, oil terminals, petrochemical industries, } \\
\text { power stations, desalination plants }\end{array}$ \\
\hline & & 02 & Sewage treatment plants and other establishments \\
\hline & & 03 & Coastal oil exploration \\
\hline & & 04 & Pipeline, outfalls and intake \\
\hline & & 05 & $\begin{array}{c}\text { Dredging, dumping, reclamation, shore and beach nourishment, } \\
\text { beach repair and construction }\end{array}$ \\
\hline & & 06 & Beach sand mining \\
\hline \multirow{3}{*}{ B } & \multirow{3}{*}{$\begin{array}{l}\text { Commercial and Residential } \\
\text { Structures and Activities }\end{array}$} & 07 & Cities and residential township, shopping malls \\
\hline & & 08 & Hotels, resorts and restaurants. \\
\hline & & 09 & Beach houses \\
\hline \multirow{2}{*}{$\mathrm{C}$} & \multirow{2}{*}{$\begin{array}{l}\text { Aesthetic and Recreational } \\
\text { Infrastructure and Activities }\end{array}$} & 10 & Artificial beaches, artificial islands, reefs, \\
\hline & & 11 & Waterfronts, aqua parks, artificial lagoons \\
\hline \multirow[t]{2}{*}{$\mathrm{D}$} & \multirow{2}{*}{$\begin{array}{c}\text { Transport structures and } \\
\text { activities }\end{array}$} & 12 & $\begin{array}{l}\text { Shipyard, port, harbors, marina, jetties, bridges, embankments, } \\
\text { runaway. }\end{array}$ \\
\hline & & 13 & $\begin{array}{l}\text { Highways and minor roads } \\
\end{array}$ \\
\hline \multirow{2}{*}{$\mathrm{E}$} & \multirow{2}{*}{$\begin{array}{l}\text { Coastal Protection Structures } \\
\text { and Activities }\end{array}$} & 14 & Groins, sea walls, riprap, revetments, break waters \\
\hline & & 15 & Sea and coastal defense projects \\
\hline
\end{tabular}

Table 4. Environmental component for Kuwait coast

\begin{tabular}{|c|c|c|c|c|}
\hline S. No. & Categories & Description & S. No. & Coastal Environmental components \\
\hline \multirow{8}{*}{01} & \multirow{8}{*}{$\begin{array}{l}\text { Physical/ } \\
\text { Chemical } \\
\text { Components } \\
\text { (PC) }\end{array}$} & \multirow{8}{*}{$\begin{array}{l}\text { Covering all physical and } \\
\text { chemical aspects of the } \\
\text { environment, including finite } \\
\text { (non-biological) natural } \\
\text { resources, and degradation of } \\
\text { the physical environment by } \\
\text { pollution. }\end{array}$} & $\mathrm{PC} 1$ & Coastline and shore \\
\hline & & & PC2 & Erosion and accretion \\
\hline & & & PC 3 & Subsidence \\
\hline & & & PC 4 & Pollution (Chemical and Thermal) \\
\hline & & & PC 5 & Natural beaches \\
\hline & & & PC 6 & Coastal land degradation \\
\hline & & & PC 7 & Coastal conflicts of human activities \\
\hline & & & PC 8 & $\begin{array}{l}\text { Geomorphology landforms (Rocky, } \\
\text { coastal sand dunes, estuaries, deltas, } \\
\text { sabkhas, khor, reef coast, sand, muddy, } \\
\text { gravely, oolitic) }\end{array}$ \\
\hline \multirow{5}{*}{02} & \multirow{5}{*}{$\begin{array}{l}\text { Biological/ } \\
\text { Ecological } \\
\text { Component } \\
\text { (BE) }\end{array}$} & \multirow{5}{*}{$\begin{array}{l}\text { Covering all biological aspects } \\
\text { of the environment, including } \\
\text { renewable natural resources, } \\
\text { conservation of biodiversity, } \\
\text { species interactions, and } \\
\text { pollution of the biosphere. }\end{array}$} & BE1 & Vegetation \\
\hline & & & BE2 & Mangrove, sea grass, etc. \\
\hline & & & BE3 & $\begin{array}{l}\text { Salt marsh, swamp, tidal flats, intertidal } \\
\text { flats, etc. }\end{array}$ \\
\hline & & & BE4 & Coral, oyster, mudskipper \\
\hline & & & BE5 & Terrestrial ecosystem \\
\hline \multirow{8}{*}{03} & \multirow{8}{*}{$\begin{array}{l}\text { Sociological/ } \\
\text { Cultural } \\
\text { Component } \\
\quad \text { (SC) }\end{array}$} & \multirow{8}{*}{$\begin{array}{l}\text { Covering all human aspects of } \\
\text { the environment, including } \\
\text { social issues affecting } \\
\text { individuals and communities; } \\
\text { together with cultural aspects, } \\
\text { including conservation of } \\
\text { heritage, and human } \\
\text { development. }\end{array}$} & $\mathrm{SC} 1$ & Human habitat and Urban Sprawl \\
\hline & & & $\mathrm{SC} 2$ & Aquaculture and fisheries \\
\hline & & & $\mathrm{SC} 3$ & Coastal land cover \\
\hline & & & $\mathrm{SC} 4$ & Cultural heritage \\
\hline & & & SC5 & Existing utilities \\
\hline & & & SC6 & Surfing, diving, swimming, boat racing, \\
\hline & & & SC7 & Site view \\
\hline & & & SC8 & Occupation and employment \\
\hline \multirow{6}{*}{04} & \multirow{6}{*}{$\begin{array}{l}\text { Economic/ } \\
\text { Operational } \\
\text { Component } \\
\quad(\text { EO) }\end{array}$} & \multirow{6}{*}{$\begin{array}{l}\text { To qualitatively identify the } \\
\text { economic consequences of } \\
\text { environmental change, both } \\
\text { temporary and permanent, as } \\
\text { well as the complexities of } \\
\text { project management within the } \\
\text { context of the project activities. }\end{array}$} & EO1 & Trade \\
\hline & & & $\mathrm{EO} 2$ & Commercial \\
\hline & & & $\mathrm{EO} 3$ & Real Estates \\
\hline & & & EO4 & Hospitality and tourism \\
\hline & & & EO5 & Navigation \\
\hline & & & EO6 & Existing utilities \\
\hline
\end{tabular}


Table 5. Environmental Scores (ES) and Range Value (RV) for Options 1-15 (With and Without Activities ) Interacting with environmental components

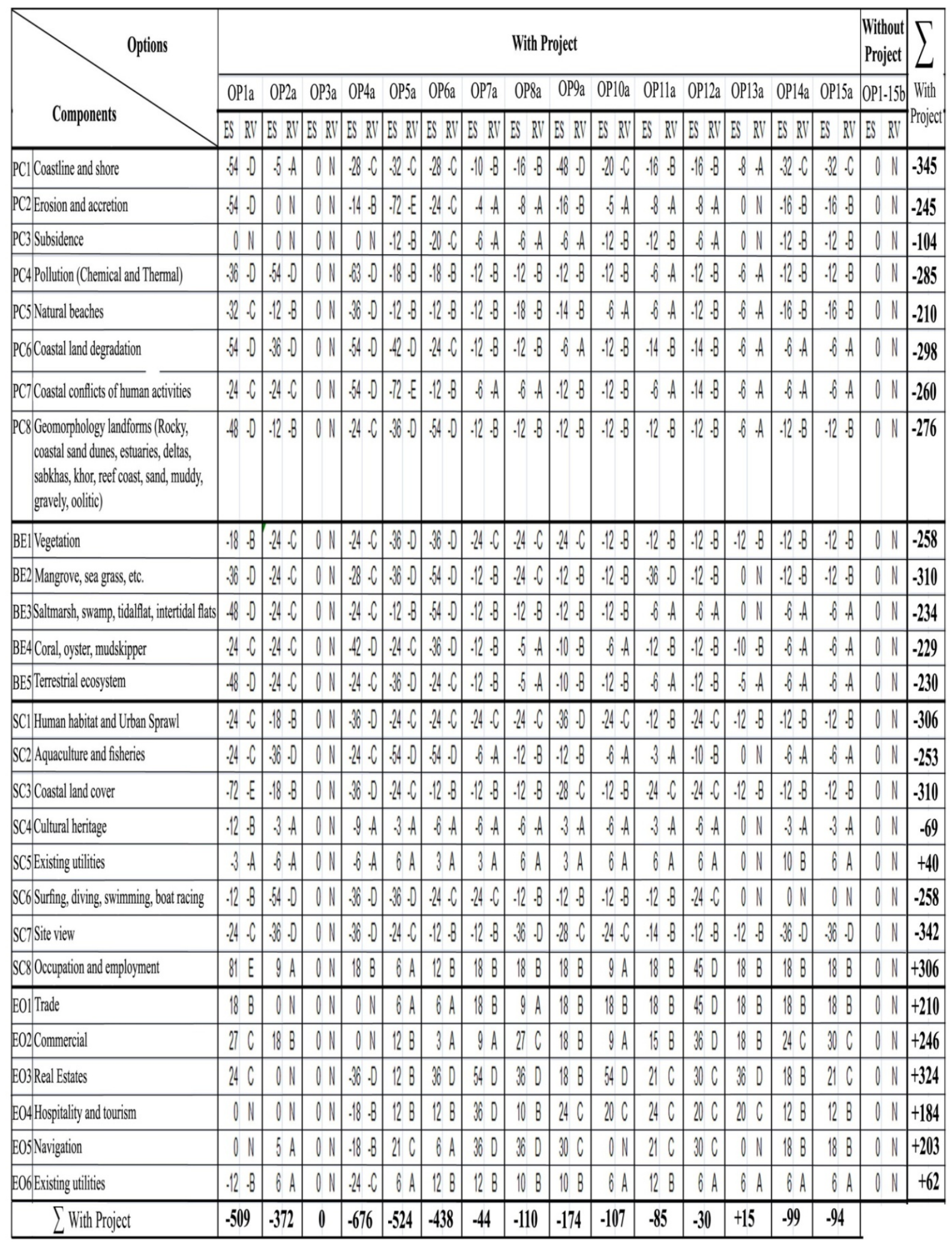


Table 6. RV and ES Values in the Categories of $\pm \mathrm{C}, \pm \mathrm{D}$ and $\pm \mathrm{E}$

\begin{tabular}{|c|c|c|c|c|c|c|c|c|c|c|}
\hline \multirow[b]{3}{*}{ S. No. } & \multirow[b]{3}{*}{ Components } & \multicolumn{9}{|c|}{ Activities with RV \& ES values for: } \\
\hline & & \multicolumn{3}{|r|}{$\pm \mathrm{C}$} & \multicolumn{3}{|c|}{$\pm \mathrm{D}$} & \multicolumn{3}{|c|}{$\pm \mathrm{E}$} \\
\hline & & $\mathrm{RV}$ & ES & $\mathrm{OPs}$ & $\mathrm{RV}$ & ES & $\mathrm{OPs}$ & $\mathrm{RV}$ & ES & OPs \\
\hline $\mathrm{PCl}$ & Coastline and shore & $\begin{array}{l}-C \\
-C \\
-C\end{array}$ & $\begin{array}{l}-32 \\
-28 \\
-20\end{array}$ & $\begin{array}{l}\text { OP5a;0P14a; 0P15a } \\
\text { OP6a } \\
\text { OP10a }\end{array}$ & $\begin{array}{l}-\mathrm{D} \\
-\mathrm{D}\end{array}$ & $\begin{array}{l}-54 \\
-48\end{array}$ & $\begin{array}{l}\mathrm{OPla} \\
\mathrm{OP} 9 \mathrm{a}\end{array}$ & & & \\
\hline PC2 & Erosion and accretion & $-\mathrm{C}$ & -24 & \begin{tabular}{|l|} 
0P6а \\
\end{tabular} & $-\mathrm{D}$ & -54 & $\mathrm{OPla}$ & $-E$ & -72 & $\begin{array}{l}\text { OP5 } \\
\mathrm{a}\end{array}$ \\
\hline PC3 & Subsidence & $-\mathrm{C}$ & -20 & 0Р6а & & & & & & \\
\hline PC4 & Pollution (Chemical and Thermal) & & & & $\begin{array}{l}-D \\
-D \\
-D\end{array}$ & $\begin{array}{l}-63 \\
-54 \\
-36\end{array}$ & $\begin{array}{l}\text { OPta } \\
\text { OP2a } \\
\text { OPla }\end{array}$ & & & \\
\hline PC5 & Natural beaches & $-\mathrm{C}$ & -32 & $\mathrm{OPla}$ & $-\mathrm{D}$ & -36 & OP4a & & & \\
\hline PC6 & Coastal land degradation & $-\mathrm{C}$ & -24 & 0Р6а & $\begin{array}{l}-D \\
-D \\
-D\end{array}$ & $\begin{array}{l}-54 \\
-42 \\
-36\end{array}$ & $\begin{array}{l}\text { OP4a; } 0 \mathrm{Pla} \\
\text { OP5a } \\
\text { OP2a }\end{array}$ & & & \\
\hline PC7 & Coastal conflicts of human activities & $-\mathrm{C}$ & -24 & OPla; OP2a & $-D$ & -54 & OP4a & $-E$ & -72 & $0 \mathrm{P5a}$ \\
\hline PC8 & $\begin{array}{l}\text { Geomorphology landforms (Rocky, coastal } \\
\text { sand dunes, estuaries, deltas, sabkhas, khhor, } \\
\text { reef coast, sand, muddr, gravelv, oolitic) }\end{array}$ & $-\mathrm{C}$ & -24 & OP4a & $\begin{array}{l}-D \\
-D \\
-D\end{array}$ & $\begin{array}{l}-54 \\
-48 \\
-36\end{array}$ & $\begin{array}{l}\text { OP6a } \\
\text { OPla } \\
\text { OP5a }\end{array}$ & & & \\
\hline BEI & Vegetation & $-\mathrm{C}$ & -24 & $\begin{array}{l}\text { OPla; OPAa; OP7a; } \\
\text { OPSa; OP9a }\end{array}$ & $-\mathrm{D}$ & -36 & OP5a; 0Р6a & & & \\
\hline $\mathrm{BE} 2$ & Mangrove, sea grass, etc. & $\begin{array}{l}-C \\
-C\end{array}$ & $\begin{array}{l}-28 \\
-24\end{array}$ & $\begin{array}{l}\text { OP4a } \\
\text { OP2a; OPSa }\end{array}$ & $\begin{array}{l}-D \\
-D\end{array}$ & $\begin{array}{l}-54 \\
-36\end{array}$ & \begin{tabular}{|l|} 
OP6a \\
OPla; OP5a
\end{tabular} & & & \\
\hline $\mathrm{BE} 3$ & $\begin{array}{l}\text { Salt marsh, swamp, tidal flats, intertidal flats, } \\
\text { etc. }\end{array}$ & $-\mathrm{C}$ & -24 & OP2a; $0 \mathrm{P} 4 \mathrm{a}$ & $\begin{array}{l}-\mathrm{D} \\
-\mathrm{D}\end{array}$ & $\begin{array}{l}-54 \\
-48\end{array}$ & $\begin{array}{l}\mathrm{OPFa} \\
\mathrm{OPla}\end{array}$ & & & \\
\hline $\mathrm{BE} 4$ & Coral, oyster,mudskipper & $-\mathrm{C}$ & -24 & OPla; OP2a; 0P5a & $-\mathrm{D}$ & $\begin{array}{l}-42 \\
-36 \\
\end{array}$ & $\begin{array}{l}\text { OP4a } \\
\text { OP6a }\end{array}$ & & & \\
\hline BE5 & Terrestrial ecosystem & $-\mathrm{C}$ & -24 & OP2a; OP4a; OP6A & $\begin{array}{l}-D \\
-D\end{array}$ & $\begin{array}{l}-48 \\
-36\end{array}$ & $\begin{array}{l}\mathrm{OPla} \\
\text { OP5a }\end{array}$ & & & \\
\hline $\mathrm{SCl}$ & Human habitat and Urban Sprawl & $-\mathrm{C}$ & -24 & $\begin{array}{l}\text { OPla; OP5a; OP6a; } \\
\text { OP7a; OP8a; OP10a; } \\
\text { OPl2a }\end{array}$ & $-D$ & -36 & OP4a; $0 \mathrm{P9a}$ & & & \\
\hline $\mathrm{SC2}$ & \begin{tabular}{|l|} 
Aquaculture and fisheries \\
\end{tabular} & $-\mathrm{C}$ & -24 & OPla; OPta & $\begin{array}{l}-\mathrm{D} \\
-\mathrm{D}\end{array}$ & $\begin{array}{l}-54 \\
-36\end{array}$ & $\begin{array}{l}\text { OP5a; OP6a } \\
\text { OP2a }\end{array}$ & & & \\
\hline $\mathrm{SC} 3$ & Coastal land cover & $-\mathrm{C}$ & -24 & $\begin{array}{l}\text { OP5a; OP9a; OPlla } \\
\text { OPl2a }\end{array}$ & $-\mathrm{D}$ & -36 & OP4a & $-E$ & -72 & $\mathrm{OPla}$ \\
\hline $\mathrm{SC} 4$ & Cultural heritage & & & & & & & & & \\
\hline SC5 & Existing utilities & & & & & & & & & \\
\hline SC6 & Surfing, diving, swimming, boat racing, & $-\mathrm{C}$ & -24 & OP6a; 0P7a; 0Pl2a & $\begin{array}{l}-D \\
-D\end{array}$ & $\begin{array}{l}-54 \\
-36\end{array}$ & $\begin{array}{l}\text { 0P2a } \\
\text { 0P4a; 0P5a }\end{array}$ & & & \\
\hline SC7 & Site riew & $\begin{array}{ll}-C \\
-C \\
-C\end{array}$ & $\begin{array}{l}-28 \\
-24\end{array}$ & $\begin{array}{l}\text { OP9a } \\
\text { OPla; OP5a; OP10a }\end{array}$ & $-\mathrm{D}$ & -36 & $\begin{array}{l}\text { OP2a; OP4a; OP8a; } \\
\text { OP14a; OP15a }\end{array}$ & & & \\
\hline SC8 & Occupation and employment & & & & $+\mathrm{D}$ & +45 & 0P12a & $+\mathrm{E}$ & +81 & $\mathrm{OPla}$ \\
\hline EOI & Trade & & & & $+\mathrm{D}$ & +45 & 0P12a & & & \\
\hline E02 & Commercial & $\begin{array}{l}+\mathrm{C} \\
+\mathrm{C} \\
+\mathrm{C} \\
\end{array}$ & $\begin{array}{l}+30 \\
+27 \\
+24 \\
\end{array}$ & $\begin{array}{l}\text { OPl5a } \\
\text { OPla; } 0 \text { OPSa } \\
\text { OPI }\end{array}$ & $+\mathrm{D}$ & +36 & 0P12a & & & \\
\hline E03 & Real Estates & $\begin{array}{l}+\mathrm{C} \\
+\mathrm{C} \\
+\mathrm{C} \\
\end{array}$ & $\begin{array}{l}+30 \\
+24 \\
+21 \\
\end{array}$ & $\begin{array}{l}\text { OPl2a } \\
\text { OPla } \\
\text { OPlla } \\
\end{array}$ & $\begin{array}{l}-\mathrm{D} \\
+\mathrm{D} \\
+\mathrm{D} \\
+\mathrm{D}\end{array}$ & $\begin{array}{r}-36 \\
+54 \\
+36 \\
+34\end{array}$ & $\begin{array}{l}\text { OP4a } \\
\text { OP7a; OPloa } \\
\text { OP6a; OP8a; OPl3a }\end{array}$ & & & \\
\hline E04 & Hospitality and tourism & $\begin{array}{l}+\mathrm{C} \\
+\mathrm{C} \\
+\mathrm{C}\end{array}$ & $\begin{array}{l}+24 \\
+20\end{array}$ & $\begin{array}{l}\text { OP9a; OPllA } \\
\text { OPl0a; OPl2a; OPl3a }\end{array}$ & $+\mathrm{D}$ & +36 & 0P7a & & & \\
\hline E05 & Narigation & $\begin{array}{l}+\mathrm{C} \\
+\mathrm{C} \\
+\mathrm{C}\end{array}$ & $\begin{array}{l}+30 \\
+21 \\
\end{array}$ & $\begin{array}{l}\text { OP9a; OPl2a } \\
\text { OP5a; OPlla }\end{array}$ & $+\mathrm{D}$ & +36 & OP7a; $0 \mathrm{P} 8 \mathrm{a}$ & & & \\
\hline E06 & Existing utilities & $-\mathrm{C}$ & -24 & $\mathrm{OP4a}$ & & & & & & \\
\hline
\end{tabular}




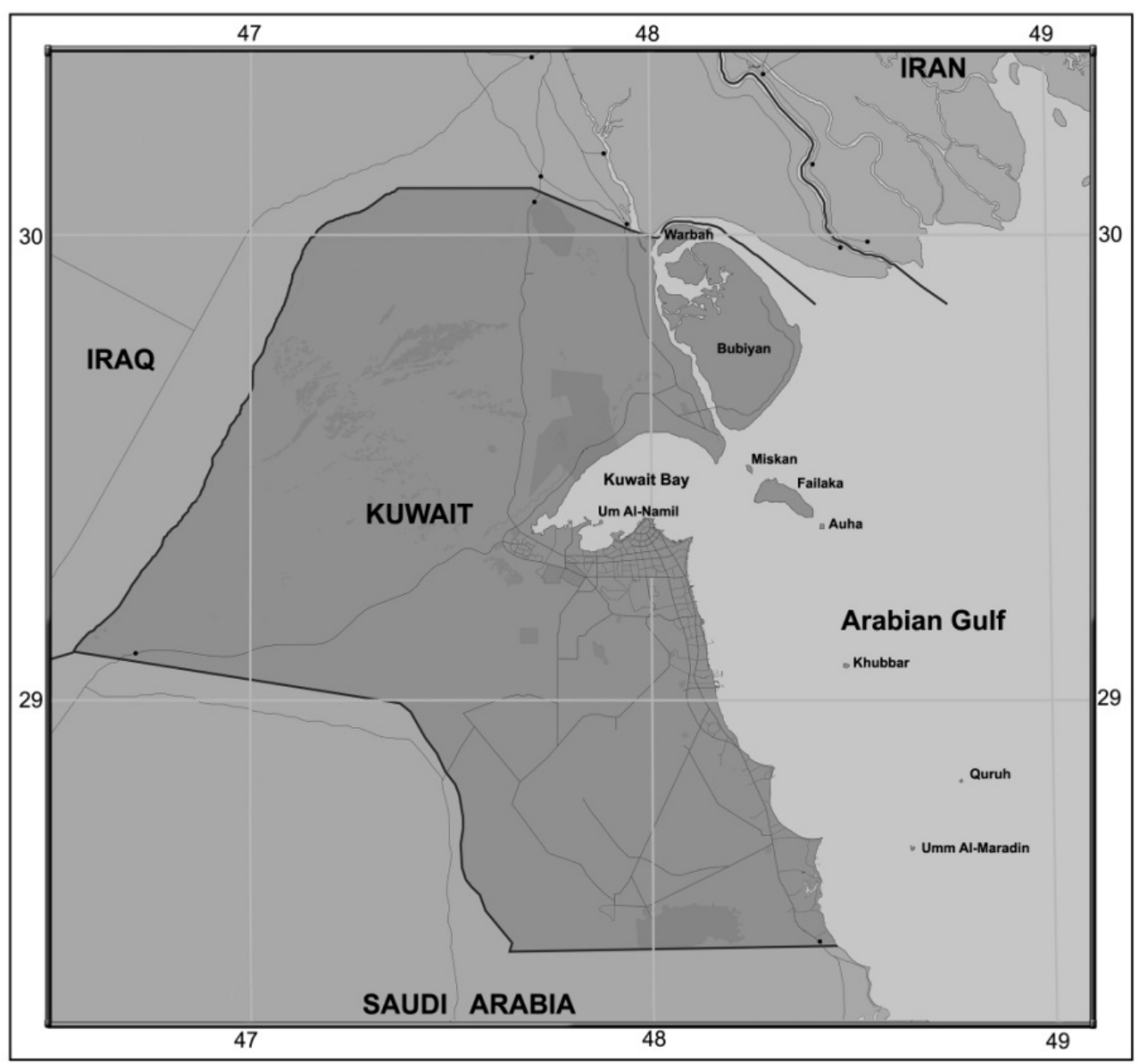

Figure 1. Kuwait Showing the Coastal Area and the Islands 


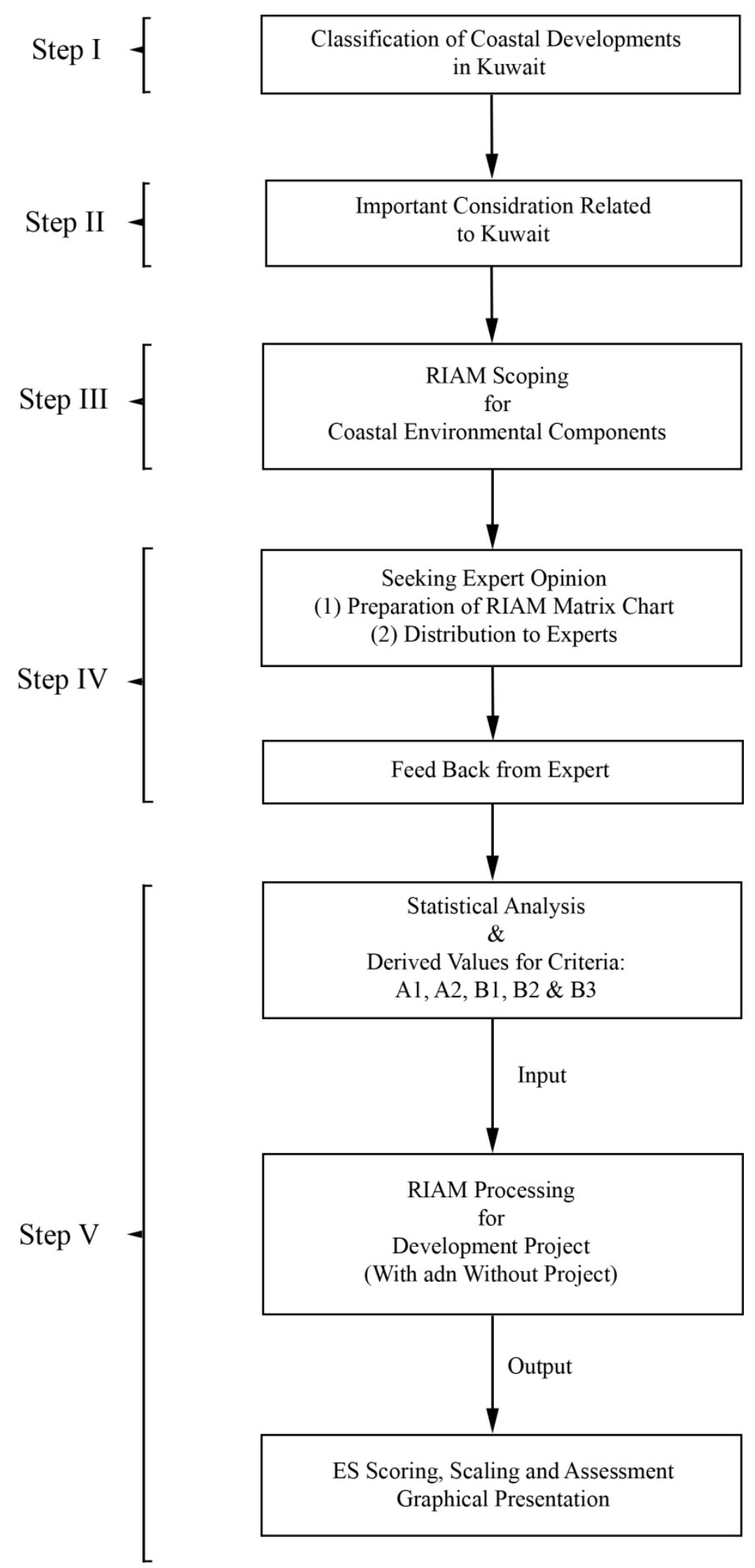

Figure 2. Flow Chart for RIAM Procedure for Assessing CMLC 


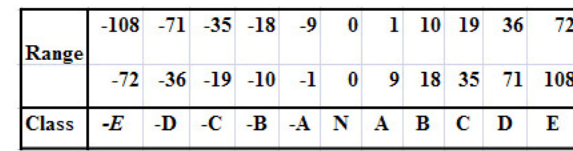

OP1a: Oil refinery complex, oil terminals, petrochemical industry, power station, desalination plant

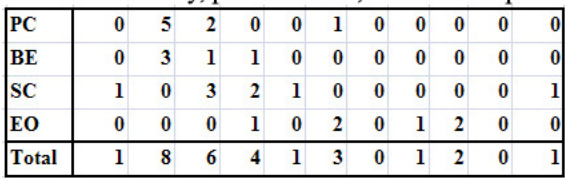

OP2a: Sewage treatment plants and other

\begin{tabular}{|c|c|c|c|c|c|c|c|c|c|c|c|}
\hline $\mathrm{PC}$ & ( & 2 & 1 & 2 & 1 & 2 & 0 & 0 & 0 & 0 & 0 \\
\hline BE & 0 & 0 & 5 & 0 & 0 & 0 & 0 & 0 & 0 & 0 & 0 \\
\hline $\mathrm{SC}$ & 0 & 3 & 0 & 2 & 2 & 0 & 1 & 0 & 0 & 0 & 0 \\
\hline EO & 0 & 0 & 0 & 0 & 0 & 3 & 2 & 1 & 0 & 0 & 0 \\
\hline Total & 0 & 5 & 6 & 4 & 3 & 5 & 3 & 1 & 0 & 0 & 0 \\
\hline
\end{tabular}

OP3a: Coastal oil exploration

\begin{tabular}{|c|c|c|c|c|c|c|c|c|c|c|c|}
\hline PC & 0 & 0 & 0 & 0 & 0 & 8 & 0 & 0 & 0 & 0 & 0 \\
\hline BE & 0 & 0 & 0 & 0 & 0 & 5 & 0 & 0 & 0 & 0 & 0 \\
\hline SC & 0 & 0 & 0 & 0 & 0 & 8 & 0 & 0 & 0 & 0 & 0 \\
\hline EO & 0 & 0 & 0 & 0 & 0 & 6 & 0 & 0 & 0 & 0 & 0 \\
\hline Total & 0 & 0 & 0 & 0 & 0 & 27 & 0 & 0 & 0 & 0 & 0 \\
\hline
\end{tabular}

OP4a: Pipeline, outfalls and intake

\begin{tabular}{|c|c|c|c|c|c|c|c|c|c|c|c|}
\hline PC & 0 & 4 & 2 & 1 & 0 & 1 & 0 & 0 & 0 & 0 & 0 \\
\hline BE & 0 & 1 & 4 & 0 & 0 & 0 & 0 & 0 & 0 & 0 & 0 \\
\hline $\mathrm{SC}$ & 0 & 4 & 1 & 0 & 2 & 0 & 0 & 1 & 0 & 0 & 0 \\
\hline EO & 0 & 1 & 1 & 2 & 0 & 2 & 0 & 0 & 0 & 0 & 0 \\
\hline Total & 0 & 10 & 8 & 3 & 2 & 3 & 0 & 1 & 0 & 0 & 0 \\
\hline
\end{tabular}

OP5a: Dredging, dumping, reclamation, shore and beach nourishment, beach repair and construction

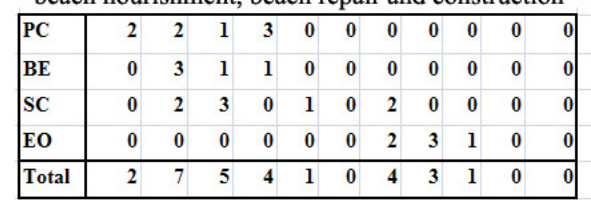

OP6a: Beach sand mining

\begin{tabular}{|c|c|c|c|c|c|c|c|c|c|c|c|}
\hline PC & 0 & 1 & 4 & 3 & 0 & 0 & 0 & 0 & 0 & 0 & 0 \\
\hline BE & 0 & 4 & 1 & 0 & 0 & 0 & 0 & 0 & 0 & 0 & 0 \\
\hline SC & 0 & 1 & 2 & 2 & 1 & 0 & 1 & 1 & 0 & 0 & 0 \\
\hline EO & 0 & 0 & 0 & 0 & 0 & 0 & 3 & 2 & 0 & 1 & 0 \\
\hline Total & 0 & 6 & 7 & 5 & 1 & 0 & 4 & 3 & 0 & 1 & 0 \\
\hline
\end{tabular}

OP7a: Cities and residential township, shopping malls

\begin{tabular}{|c|c|c|c|c|c|c|c|c|c|c|c|}
\hline PC & 0 & 0 & 0 & 5 & 3 & 0 & 0 & 0 & 0 & 0 & 0 \\
\hline $\mathrm{BE}$ & 0 & 0 & 1 & 4 & 0 & 0 & 0 & 0 & 0 & 0 & 0 \\
\hline SC & 0 & 0 & 2 & 2 & 2 & 0 & 1 & 1 & 0 & 0 & 0 \\
\hline EO & 0 & 0 & 0 & 0 & 0 & 0 & 1 & 2 & 0 & 3 & 0 \\
\hline Total & 0 & 0 & 3 & 11 & 5 & 0 & 2 & 3 & 0 & 3 & 0 \\
\hline
\end{tabular}

OP8a: Hotels, resorts and restaurants.

\begin{tabular}{|l|l|l|l|l|l|l|l|l|l|l|l|}
\hline $\mathrm{PC}$ & 0 & 0 & 0 & 5 & 3 & 0 & 0 & 0 & 0 & 0 & 0 \\
\hline $\mathrm{BE}$ & 0 & 0 & 2 & 1 & 2 & 0 & 0 & 0 & 0 & 0 & 0 \\
\hline $\mathrm{SC}$ & 0 & 1 & 1 & 3 & 1 & 0 & 1 & 1 & 0 & 0 & 0 \\
\hline EO & 0 & 0 & 0 & 0 & 0 & 0 & 1 & 2 & 1 & 2 & 0 \\
\hline Total & 0 & 1 & 3 & 9 & 6 & 0 & 2 & 3 & 1 & 2 & 0 \\
\hline
\end{tabular}

\begin{tabular}{|l|c|c|c|c|c|c|c|c|c|c|c|}
\hline \multirow{2}{*}{ Range } & -108 & -71 & -35 & -18 & -9 & 0 & 1 & 10 & 19 & 36 & 72 \\
& -72 & -36 & -19 & -10 & -1 & 0 & 9 & 18 & 35 & 71 & 108 \\
\hline Class & $-\mathrm{E}$ & $-\mathrm{D}$ & $-\mathrm{C}$ & $-\mathrm{B}$ & $-\mathrm{A}$ & $\mathrm{N}$ & $\mathrm{A}$ & $\mathrm{B}$ & $\mathrm{C}$ & $\mathrm{D}$ & $\mathrm{E}$ \\
\hline
\end{tabular}

OP9a: Beach houses

\begin{tabular}{|c|c|c|c|c|c|c|c|c|c|c|}
\hline PC & 0 & 1 & 0 & 5 & 2 & 0 & 0 & 0 & 0 & 0 \\
\hline BE & 0 & 0 & 1 & 4 & 0 & 0 & 0 & 0 & 0 & 0 \\
\hline SC & 0 & 1 & 2 & 2 & 1 & 0 & 1 & 1 & 0 & 0 \\
\hline EO & 0 & 0 & 0 & 0 & 0 & 0 & 0 & 4 & 2 & 0 \\
\hline Total & 0 & 2 & 3 & 11 & 3 & 0 & 1 & 5 & 2 & 0 \\
\hline
\end{tabular}

OP10a: Artificial beaches, artificial islands, reefs,

\begin{tabular}{|l|l|l|l|l|l|l|l|l|l|l|l|}
\hline PC & 0 & 0 & 1 & 5 & 2 & 0 & 0 & 0 & 0 & 0 & 0 \\
\hline BE & 0 & 0 & 0 & 4 & 1 & 0 & 0 & 0 & 0 & 0 & 0 \\
\hline SC & 0 & 0 & 2 & 2 & 2 & 0 & 2 & 0 & 0 & 0 & 0 \\
EO & 0 & 0 & 0 & 0 & 0 & 1 & 2 & 1 & 1 & 1 & 0 \\
\hline Total & 0 & 0 & 3 & 11 & 5 & 1 & 4 & 1 & 1 & 1 & 0 \\
\hline
\end{tabular}

OP11a: Waterfronts, aqua parks, artificial lagoons

\begin{tabular}{|l|l|l|l|l|l|l|l|l|l|l|l|}
\hline PC & 0 & 0 & 0 & 4 & 4 & 0 & 0 & 0 & 0 & 0 & 0 \\
\hline BE & 0 & 1 & 0 & 2 & 2 & 0 & 0 & 0 & 0 & 0 & 0 \\
\hline SC & 0 & 0 & 1 & 3 & 2 & 0 & 1 & 1 & 0 & 0 & 0 \\
EO & 0 & 0 & 0 & 0 & 0 & 0 & 0 & 3 & 3 & 0 & 0 \\
\hline Total & 0 & 1 & 1 & 9 & 8 & 0 & 1 & 4 & 3 & 0 & 0 \\
\hline
\end{tabular}

OP12a: Shipyard, port, harbors, marina, jetties, bridges, embankments, runaway

\begin{tabular}{|l|r|r|r|r|r|r|r|r|r|r|r|}
\hline PC & 0 & 0 & 0 & 6 & 2 & 0 & 0 & 0 & 0 & 0 & 0 \\
BE & 0 & 0 & 0 & 4 & 1 & 0 & 0 & 0 & 0 & 0 & 0 \\
SC & 0 & 0 & 3 & 2 & 1 & 0 & 1 & 0 & 0 & 1 & 0 \\
EO & 0 & 0 & 0 & 0 & 0 & 0 & 1 & 0 & 3 & 2 & 0 \\
\hline Total & 0 & 0 & 3 & 12 & 4 & 0 & 2 & 0 & 3 & 3 & 0 \\
\hline
\end{tabular}

OP13a: Highways and minor roads

\begin{tabular}{|l|r|r|r|r|r|r|r|r|r|r|r|}
\hline PC & 0 & 0 & 0 & 0 & 6 & 2 & 0 & 0 & 0 & 0 & 0 \\
\hline BE & 0 & 0 & 0 & 2 & 1 & 2 & 0 & 0 & 0 & 0 & 0 \\
\hline SC & 0 & 0 & 0 & 3 & 0 & 4 & 0 & 1 & 0 & 0 & 0 \\
\hline EO & 0 & 0 & 0 & 0 & 0 & 1 & 1 & 2 & 1 & 1 & 0 \\
\hline Total & 0 & 0 & 0 & 5 & 7 & 9 & 1 & 3 & 1 & 1 & 0 \\
\hline
\end{tabular}

OP14a: Groins, sea walls, riprap, revetments,

break waters

\begin{tabular}{|c|c|c|c|c|c|c|c|c|c|c|c|}
\hline PC & 0 & 0 & 1 & 5 & 2 & 0 & 0 & 0 & 0 & 0 & 0 \\
\hline BE & 0 & 0 & 0 & 2 & 3 & 0 & 0 & 0 & 0 & 0 & 0 \\
\hline $\mathrm{SC}$ & 0 & 1 & 0 & 2 & 2 & 1 & 0 & 2 & 0 & 0 & 0 \\
\hline EO & 0 & 0 & 0 & 0 & 0 & 0 & 1 & 4 & 1 & 0 & 0 \\
\hline Total & 0 & 1 & 1 & 9 & 7 & 1 & 1 & 6 & 1 & 0 & 0 \\
\hline
\end{tabular}

OP15a: Sea and coastal defense projects

\begin{tabular}{|l|l|l|l|l|l|l|l|l|l|l|l|}
\hline PC & 0 & 0 & 1 & 5 & 2 & 0 & 0 & 0 & 0 & 0 & 0 \\
\hline BE & 0 & 0 & 0 & 2 & 3 & 0 & 0 & 0 & 0 & 0 & 0 \\
SC & 0 & 1 & 0 & 2 & 2 & 1 & 1 & 1 & 0 & 0 & 0 \\
EO & 0 & 0 & 0 & 0 & 0 & 0 & 1 & 3 & 2 & 0 & 0 \\
\hline Total & 0 & 1 & 1 & 9 & 7 & 1 & 2 & 4 & 2 & 0 & 0 \\
\hline
\end{tabular}

OP1b-15b: Without project

\begin{tabular}{|c|c|c|c|c|c|c|c|c|c|c|c|}
\hline PC & 0 & 0 & 0 & 0 & 0 & 8 & 0 & 0 & 0 & 0 & 0 \\
\hline $\mathrm{BE}$ & 0 & 0 & 0 & 0 & 0 & 5 & 0 & 0 & 0 & 0 & 0 \\
\hline $\mathrm{SC}$ & 0 & 0 & 0 & 0 & 0 & 8 & 0 & 0 & 0 & 0 & 0 \\
\hline EO & 0 & 0 & 0 & 0 & 0 & 6 & 0 & 0 & 0 & 0 & 0 \\
\hline Total & 0 & 0 & 0 & 0 & 0 & 27 & 0 & 0 & 0 & 0 & 0 \\
\hline
\end{tabular}

Figure 3. Summation of RV 


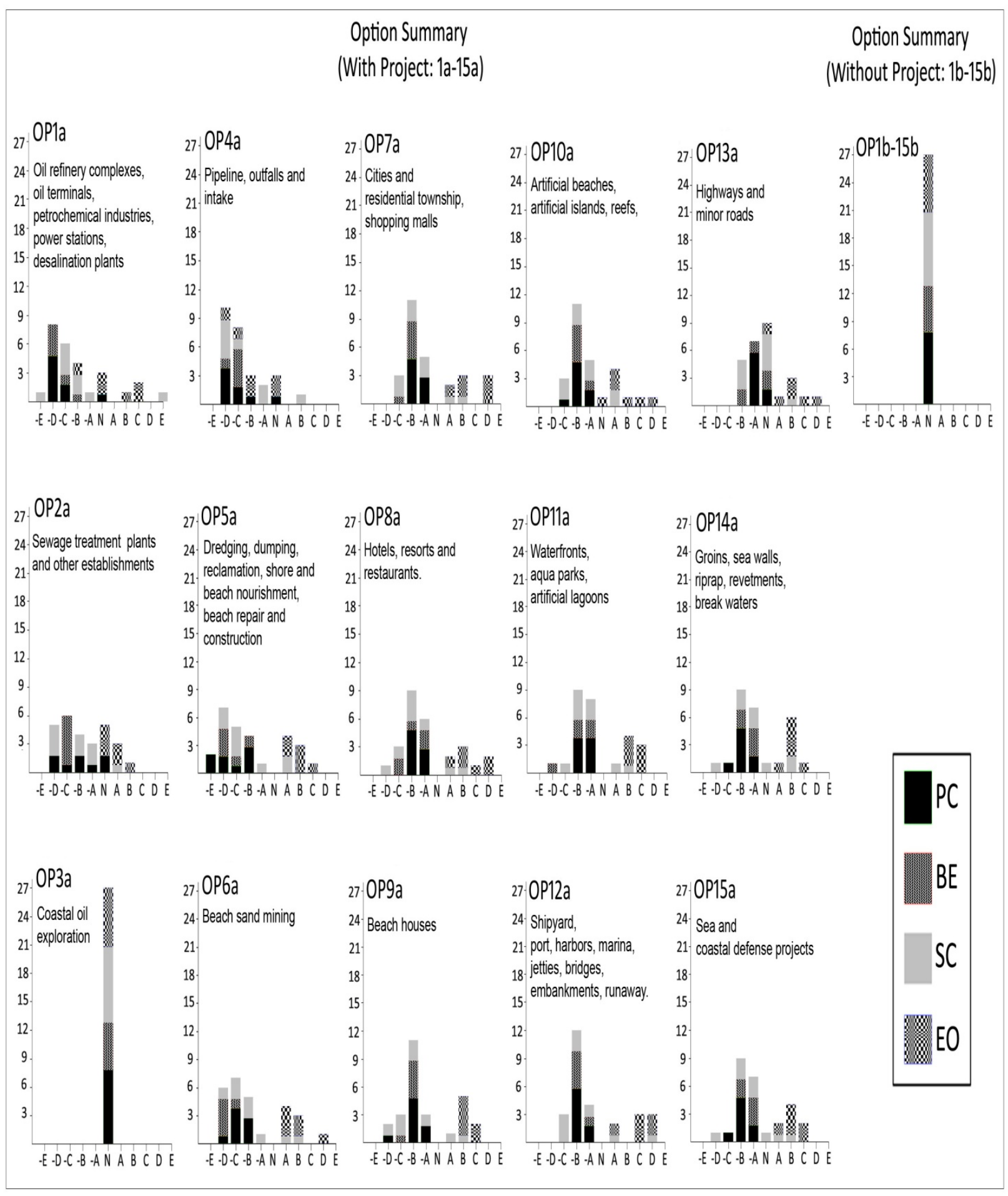

Figure 4. Histogram for Environmental Scores (ES) and Range Value (RV) for With Project and Without Project 


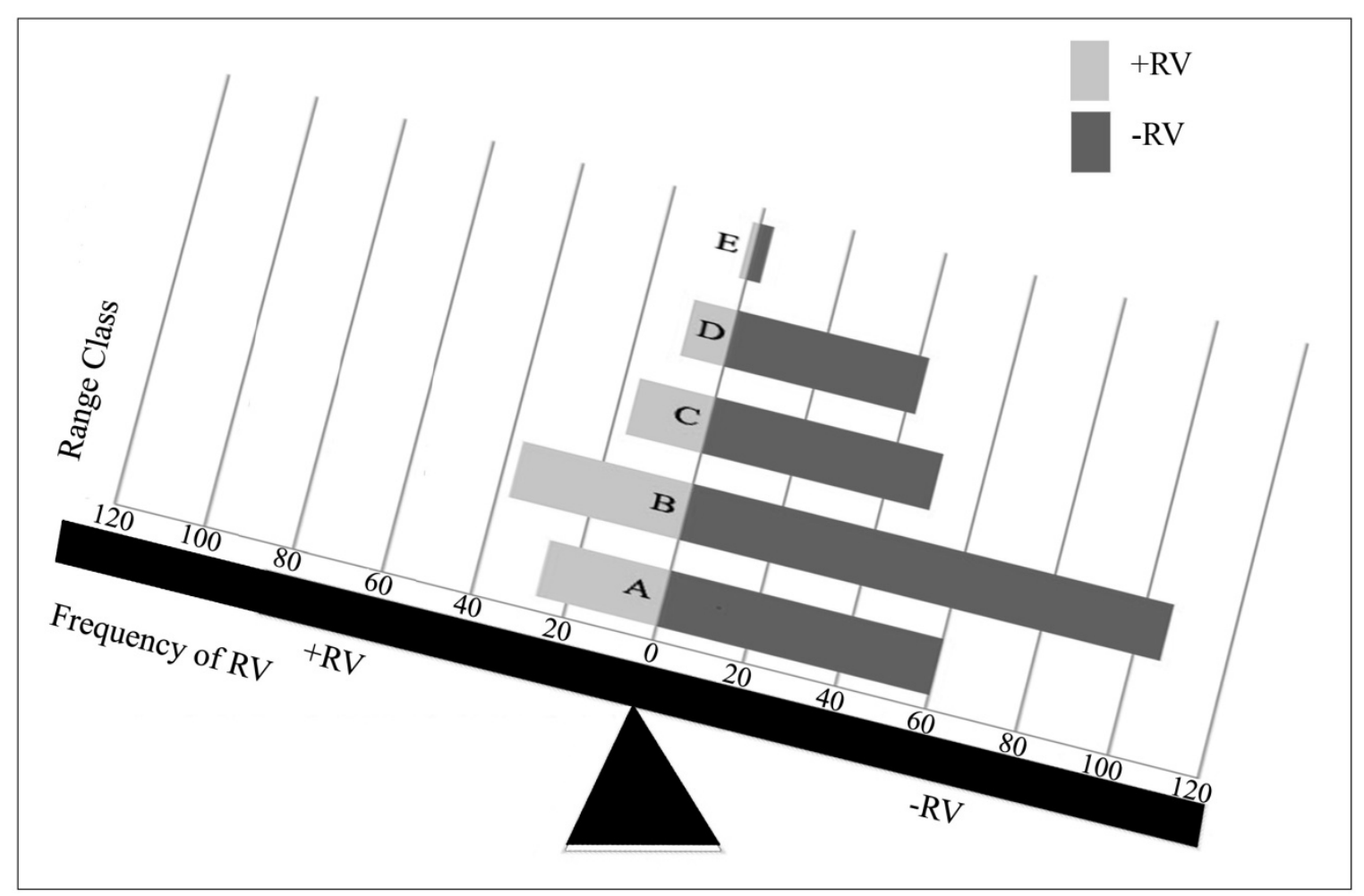

Figure 5. RV Frequency Balance 